\section{Obesity in Canines: Issues, Causes, Treatments and Managements}

\author{
Sagar Regmi ${ }^{1 *}$ \\ Agriculture and forestry university, Rampur, Nepal
}

\begin{abstract}
Obesity is a nutritional disorder resulting due to positive energy balance in which excessive amount of adipose tissue is accumulated in the body of an organism. Determination of degree of obesity depends mainly on Body Condition Score (BCS) estimated by palpation of ribs, tail base etc. Dog with BCS " 5 or 9" is considered to be obese depending on the system chosen i.e. 5 or 9 point system. Various metabolic disorder, neutering, age and sex, unhealthy diet etc. can be major causes of obesity. Osteoarthritis is one of the major issues related to obesity followed by cardiopulmonary disorder, urolithiasis, reproductive disorder etc. There is no specific treatment for obesity but dietary management plays pivotal role in weight reduction. Dietary management mainly includes L-carnitine and conjugated linoleic acid. L-carnitine enhances fatty acid oxidation whereas conjugated linoleic acid acts by inhibiting Stearoyl-CoA desaturase activity, which prevents the synthesis of monounsaturated fatty acids. Some Microsomal Triglyceride Transfer (MTP) protein inhibitors are also manufactured recently which prevents formation of chylomicrons and prevents its absorption from intestine.
\end{abstract}

Keywords: Adipokines; Chylomicrons; Conjugated linoleic acid; L-carnitine; Osteoarthritis; Urolithiasis

\section{Introduction}

Dogs are kept as a companion animal from centuries. Obesity is one of the major issues seen in canines maintained on a highly nutritious diet with lower exercise for energy utilization leading to positive energy balance [1]. It can be defined as an accumulation of excessive amounts of adipose tissue in the body. Dogs with body weight 15- 30 percent above normal is considered to be obese (17_Clinical_Weight Management_for_Dogs_and_Cats.pdf, n.d.). Determination of obese

*Corresponding author: Sagar Regmi, Agriculture and forestry university, Rampur, Nepal, Tel: +977 9860410963; E-mail: saregme@gmail.com

Citation: Regmi S (2020) Obesity in Canines: Issues, Causes, Treatments and Managements. J Cell Biol Cell Metab 7: 022.

Received: July 21, 2020; Accepted: August 11, 2020; Published: August 18, 2020

Copyright: $\odot 2020$ Regmi S. This is an open-access article distributed under the terms of the Creative Commons Attribution License, which permits unrestricted use, distribution, and reproduction in any medium, provided the original author and source are credited. condition in dogs mainly depends on (Table 1) fat mass and lean body mass. Body Mass Index (BMI) is used as a rough indication for obesity determination in humans. BMI in dogs can be predicted by calculating the ratio of pelvic circumference to the distance between the patella and the hock joint. Dogs are categorized as overweight and obese when BMI is greater than $25 \mathrm{~kg} / \mathrm{m}^{2}$ and $30 \mathrm{~kg} / \mathrm{m}^{2}$ respectively. Some reports also suggested that dogs are overweight and obese when their body weight exceeds $15 \%$ and $30 \%$ above their normal body weight respectively [2]. But this technique proves to be unsuccessful due to the presence of diverse number of breeds with altered conformation [3]. The Body Condition Score (BCS) technique is also widely used for assessment of obesity and depends on visual interpretation (Table 2) and palpation of various body parts like ribs, tail base etc. to determine the amount of fat present. There are two main systems to determine the degree of obesity i.e. 5 and 9 point system in which " 1 " is considered to be emaciated and " 5 or 9" is considered to be obese based on system chosen.

\begin{tabular}{|c|c|l|c|}
\hline Condition & BCS & \multicolumn{1}{|c|}{ Findings } & Fat (\%) \\
\hline Very thin & $1 / 5$ & easily palpable rib cage, prominent bony structures & 0 \\
\hline Lean & $2 / 5$ & Skeletal structure visible & 10 \\
\hline Optimal & $3 / 5$ & $\begin{array}{l}\text { easily palpable rib cage but not showing, smooth } \\
\text { contour of tail base }\end{array}$ & 20 \\
\hline Overweight & $4 / 5$ & barely palpable rib cage, tail base thickened & 30 \\
\hline Obese & $5 / 5$ & Rib cage can't be palpated, tail base barely palpable & 40 \\
\hline
\end{tabular}

Table 1: Body Condition Scoring for dogs, adapted from Nelson and Couto.

\begin{tabular}{|c|c|c|}
\hline Condition & BCS & Findings \\
\hline Thin Dog & 1 & $\begin{array}{l}\text { Ribs, lumbar vertebrae, and pelvic bones easily visible, No pal- } \\
\text { pable fat, Obvious waist and abdominal tuck, Prominent pelvic } \\
\text { bones }\end{array}$ \\
\hline $\begin{array}{l}\text { Underweight } \\
\text { Dog }\end{array}$ & 3 & $\begin{array}{l}\text { Ribs easily palpable, Minimal fat covering, Waist easily noted } \\
\text { when viewed from above, Abdominal tuck evident }\end{array}$ \\
\hline Ideal Dog & 5 & $\begin{array}{l}\text { Ribs palpable, but not visible, Waist observed behind ribs when } \\
\text { viewed from above, abdomen tucked up when viewed from side }\end{array}$ \\
\hline $\begin{array}{l}\text { Overweight } \\
\text { Dog }\end{array}$ & 7 & $\begin{array}{l}\text { Ribs palpable with slight excess of fat covering, Waist discern- } \\
\text { ible when viewed from above, but not prominent, Abdominal } \\
\text { tuck apparent }\end{array}$ \\
\hline Obese Dog & 9 & $\begin{array}{l}\text { Ribs not easily palpable under a heavy fat covering, Fat depos- } \\
\text { its over lumbar area and tail base, Waist barely visible to absent, } \\
\text { No abdominal tuck; may exhibit obvious abdominal distention }\end{array}$ \\
\hline \multicolumn{3}{|r|}{ Table 2: Body Condition Scoring for dogs [4]. } \\
\hline
\end{tabular}

The major constraints of BCS methods include the subjectivity of the measure, variation in the shape of body among different individuals and breeds and the fact that BCS does not consider lean mass during evaluation [5].

The adipokines are cytokines or signaling proteins synthesized by adipose tissue. Leptin was the first discovered adipokine in 1994. Leptin and adiponectin are the two major fat-derived adipokines. Leptin (composed of 167 amino acids) is a hormone discovered to 
be produced by a gene named "Ob gene" located on chromosome number 7. In humans this hormone is produced mainly by the white adipose tissue and binds to a receptor present in brain responsible for controlling appetite [6]. Adiponectin (composed of 244 amino acids) is also a hormone produced mainly by mature adipocytes which contributes to increase insulin sensitivity, involved in glucose homeostasis and beta-oxidation of fatty acids. Relative or absolute deficiency of this hormone in circulation leads to obesity [7].

Various modern techniques like dual x-ray absorptiometry scan, deuterium oxide analysis, bioelectrical impedance analysis, densitometry, computed tomography, dilution methods, magnetic resonance imaging, neutron activation analysis etc. have been discovered to determine whether an animal is obese or not.

\section{Causes of Obesity}

\section{Metabolic and endocrine disorder}

Leptin and adiponectin are two major endocrine hormones associated with obesity. The fluctuation of leptin above or below the normal level circulating in the body results in uncontrolled feeding and results obesity [8]. Hypothyroidism, hyper-adrenocortism, diabetes mellitus, hypopituitarism, hyper-lipidemia and glucose intolerance can lead to obesity [9].

\section{Effects of medicines}

Drug-induced polyphagia caused by glucocorticoids and anticonvulsant drugs also causes obesity. Some chemicals like Gold thioglucose and monosodium glutamate were found to induce obesity in rodents. Most of the drug except antipsychotics doesn't possess any side-effects of inducing obesity. These drugs are believed to impair mitochondrial beta-oxidation of fatty acids, decrease energy expenditure and altered activity of hypothalamic leptin and neuropeptide $\mathrm{Y}$ which ultimately results obese condition in dogs [10].

\section{Neutering}

Spaying or neutering of dog's results in hormonal alterations that influence appetite, glucose tolerance, and adipose and lipid metabolism. Many studies revealed that the decrease in concentration of sex hormones leads to a decrease (25-30\%) in metabolic rate after neutering resulting obesity [11].

\section{Dietary factors and human-animal bond}

Diet can also lead to the development of obesity in both dogs and cats due to impaired glucose tolerance, dysplipidemia, and insulin resistance when fed a high-fat, high-sucrose, and high-caloric diet (Levin \& Dunn-Meynell, 2002). Diet-induced obesity is associated with insensitivity to leptin with high-circulating leptin levels leading to 'leptin resistance' [12]. Leptin is mainly associated with appetite control. Obesity in dogs is associated with the number of meals and snacks fed by their owners irrespective to their caloric value, the feeding of table scraps, and the dog's presence when its owners prepared or ate their own meal [13].

\section{Genetic factors}

Opined that some dog breeds possess $[14,15]$ higher predisposition to obesity. Labrador Retrievers were found to have higher chance of developing obesity. Some other breeds with chances of being obese includes Cairn terriers, Cocker spaniels, long-haired Dachshunds, Shetland sheepdogs, Basset hounds, Cavalier King Charles spaniels and Beagles. Greyhound is resistant of obesity.

\section{Issues related to obesity}

\section{Orthropedic disorder}

Osteoarthritis, Fractures (primarily humeral condyles), Cruciate ligament tears/rupture, Intervertebral disk disease are the major disorders associated with obesity in dogs. The increased body weight during obesity exerts excessive pressure on the joint and ligaments leading to degenerative effects and lameness. A number of studies depicted the relation between obesity and occurrence of osteoarthritis [16] and similarly the reduction in body weight can lead to improvement in the degree of lameness in dogs [17].

\section{Diabetes}

It is a common endocrinopathy in dogs of today's date resulting due to insulin deficiency. Lower level of adiponectin in obesity contribute to peripheral insulin resistance resembling the type I diabetes mellitus of humans [18]. The decreased level of adiponectin is due to increased production of pro-inflammatory cytokines like TNF and IL-6 [19].

\section{Respiratory distress}

Weight gain and rising BMI in human's leads to decrease in lung volume resulting restrictive type of ventilatory pattern on spirometer $[20,21]$ also demonstrated that the incidence of asthma is higher in individual with higher BMI. So, it is also similar to dogs as that of humans. Excessive fat on the body of obese dog hinders the movement of diaphragm (expansion and relaxation) during respiration [22].

\section{Heart diseases}

Increased inter-ventricular septal width in diastole to left ventricular internal dimension in diastole ratio, decreased ratios of peak early to peak late left ventricular inflow velocities, and ratios of peak early to peak late mitral annular tissue velocities, and increased fractional shortening and ejection fraction percentages are the major cardiac changes associated with obese dogs over normal ones [23]. The metabolic alterations can result in cardiac dysfunction as a result of altered cardiac mitochondrial metabolism and resulting in intramyocardial lipid accumulation [24]. In the study performed by [25] Body Condition Score (BCS), modified body mass index (MBMI, $\mathrm{kg} / \mathrm{m} 2$ ) and ab-dominal obesity were compared between healthy dogs and dogs affected with heart disease. The average BCS was found to be comparable between healthy dogs and dogs with heart disease. But the average MBMI was significantly higher in dogs with heart disease than in healthy dogs. Increased level of body fat in obese animals leads to increased blood pressure and can cause congestive heart failure [26].

\section{Reproductive disorder}

Obesity is associated with multiple reproductive disorders like infertility, ovulation dysfunction, fetal growth disorders and abortion too in some cases [27]. Obese animals possess higher risk of dystocia due to accumulation of fatty tissues around the pelvic cavity reducing the elasticity of pelvic ligaments which is must for parturition [28]. 


\section{Urinary disorders}

Increased retroperitoneal fat in obese dogs causes caudal displacements of urinary bladder leading to difficult and painful micturition. Some researchers have reported the higher incidence of urolithiasis in obese animals than normal ones [29]. Excess body weight in obese dogs causes increased abdominal pressure, which in turn leads to increased urethral mobility and bladder pressure, resulting to stress induced urinary incontinence [30].

\section{Treatment and management}

There are no specific pharmacological products for the correction of obesity. It mainly involves dietary management and physical exercise for weight reduction. Control of obesity will subsequently prevent all other effects on heart, urinary bladder, joints etc.

\section{Dietary management}

Dietary factors for weight reduction mainly include L-carnitine conjugated linoleic acid (CLA), and high-fiber diets.

- L-Carnitine is synthesized by De-novo pathway in the liver and kidneys from lysine and methionine in the presence of ascorbate. L-carnitine (@50-300 ppm) enhances nitrogen retention and reduces fatty tissues from the body. It acts by enhancing fatty acid oxidation and energy availability for protein synthesis during times of need [31].

- Conjugated linoleic acid is derived from linoleic acid and discovered to possess anti-adipogenic effect through various researches. It inhibits Stearoyl-CoA desaturase activity, which inhibits the synthesis of monounsaturated fatty acids involved in triglyceride synthesis, and ultimately suppresses elongation and desaturation of fatty acids into long-chain fatty acids [32].

- In obese dogs the production of mediators of inflammation derived from adipose tissue is increased. So, diets enriched with omega-3 polyunsaturated fatty acids can be proven beneficial by reducing the production of lipid inflammatory mediators [33].

Obese dog provided with low-fat diet was found to have decreased level of serum [34]. Decrease in the degree of hindlimb lameness was found in obese dogs with coxofemoral osteoarthritis following diet-induced weight loss. Significant reductions in total serum cholesterol concentrations and systolic, diastolic and mean arterial blood pressures was noticed in dogs made obese with a high-fat diet then placed on a low-fat diet [35].

\section{Exercise and lifestyle management}

Dietary therapy used in conjunction with exercise facilitates rapid fat loss. Various exercises for canines include walking, running, hydrotherapy, treadmill, swimming [36] etc. The combined people and pet exercise program conducted by [37] documented the weight loss in both owner and pet where $15 \%$ of weight was reduced in case of dogs.

Note: Recently two anti-obesity drugs (Dirlotapide, Mitratapide) containing microsomal triglyceride transfer (MTP) protein inhibitors are formulated [38]. These drugs reduce the packaging of fatty acids and proteins into chylomicrons in the enterocytes of small intestine which is driven by MTP activity. Intracellular accumulation of fat molecules due to MTP inhibition stimulates the release of peptide YY from the enterocyte of villi. The Peptide YY suppresses the synthesis of satiety hormone essential for signaling hypothalamus to control feed intake.

\section{Conclusion}

Obesity associated osteoarthritis and other detrimental effects in dogs can be controlled by exercise and dietary management. High fiber containing diet is to be provided to dogs as it contains lower nutritive value. Strict daily diet plan must be formulated for dogs with optimum energy and protein requirement. BCS of dog must be calculated by every veterinarian during each visit to determine whether an animal is obese or not.

\section{Acknowledgement}

I would like to convey my deepest gratitude to my friends, teachers and parents for their continuous support throughout the journey.

\section{References}

1. German AJ (2006) The Growing Problem of Obesity in Dogs and Cats. The Journal of Nutrition 136: 1940-1946.

2. Burkholder WJ (2000) Use of body condition scores in clinical assessment of the provision of optimal nutrition. Journal of the American Veterinary Medical Association 217: 650-654.

3. McGreevy PD, Thomson PC, Pride C, Fawcett A, Grassi T, et al. (2005) Prevalence of obesity in dogs examined by Australian veterinary practices and the risk factors involved. Veterinary Record 156: 695-702.

4. Smart M (2000) Recent Advances in Canine and Feline Nutrition, Vol II: 1998 lams Nutrition Symposium. The Canadian Veterinary Journal 41: 243.

5. Otsuji K, Koizumi A, Kobayashi N, Suzuki M, Furukawa N, et al. (2016) The effectiveness of the body condition score model for the nutritional assessment in dogs. Journal of Pet Animal Nutrition 19: 15-20.

6. An Endocrine Approach to Obesity in Dogs-VetFolio (n.d.). (2020) Retrieved from https:/www.vetfolio.com/learn/article/an-endocrine-approach-to-obesity-in-dogs.

7. Forny-Germano L, De Felice FG, Vieira MN do N (2019) The Role of Leptin and Adiponectin in Obesity-Associated Cognitive Decline and Alzheimer's Disease. Frontiers in Neuroscience 12: 1-19.

8. Schwartz MW, Woods SC, Porte D, Seeley RJ, Baskin DG (2000) Central nervous system control of food intake. Nature 404: 661-671.

9. Tvarijonaviciute A, Ceron JJ, Holden SL, Cuthbertson DJ, Biourge V, et al. (2012) Obesity-related metabolic dysfunction in dogs: A comparison with human metabolic syndrome. BMC Veterinary Research 8: 147.

10. Wakshlag J, Loftus J (2014) Canine and feline obesity: A review of pathophysiology, epidemiology, and clinical management. Veterinary Medicine: Research and Reports 2015: 49-60.

11. Harper EJ, Stack DM, Watson TDG, Moxham G (2001) Effects of feeding regimens on bodyweight, composition and condition score in cats following ovariohysterectomy. Journal of Small Animal Practice 42: 433438

12. Lennarz WJ, Lane MD (2013) Encyclopedia of biological chemistry. Academic Press 3232.

13. Kienzle E, Bergler R, Mandernach A (1998) A Comparison of the Feeding Behavior and the Human-Animal Relationship in Owners of Normal and Obese Dogs. The Journal of Nutrition 128: 2779-2782. 
14. Edney AT, Smith PM (1986) Study of obesity in dogs visiting veterinary practices in the United Kingdom. The Veterinary Record 118: 391-396.

15. Kronfeld DS, Donoghue S, Glickman LT (1991) Body Condition and Energy Intakes of Dogs in a Referral Teaching Hospital. The Journal of Nutrition 121: 157-158.

16. Kealy RD, Lawler DF, Balla JM, Lust G, Smith GK, et al. (1997) Fiveyear longitudinal study on limited food consumption and developmen of osteoarthritis in coxofemoral joints of dogs. Journal of the American Veterinary Medical Association 210: 222-225.

17. Impellizeri JA, Tetrick MA, Muir P (2000) Effect of weight reduction on clinical signs of lameness in dogs with hip osteoarthritis. Journal of the American Veterinary Medical Association 216: 1089-1091.

18. Lawler DF, Evans RH, Larson BT, Spitznagel EL, Ellersieck MR, et al. (2005) Influence of lifetime food restriction on causes, time, and predictors of death in dogs. Journal of the American Veterinary Medical Association 226: $225-231$

19. Kim AY, Kim HS, Kang JH, Yang MP (2015) Serum adipokine concentrations in dogs with diabetes mellitus: A pilot study. Journal of Veterinary Science 16: 333-340.

20. Zammit C, Liddicoat H, Moonsie I, Makker H (2010) Obesity and respiratory diseases. International Journal of General Medicine 3: 335-343.

21. Schachter LM (2001) Obesity is a risk for asthma and wheeze but not airway hyperresponsiveness. Thorax 56: 4-8.

22. White RAS, Williams JM (1994) Tracheal collapse in the dog - is there really a role for surgery? A survey of 100 cases. Journal of Small Animal Practice 35: 191-196.

23. Tropf M, Nelson OL, Lee PM, Weng HY (2017) Cardiac and Metabolic Variables in Obese Dogs. Journal of Veterinary Internal Medicine 31: 1000-1007.

24. Park SY, Cho YR, Kim HJ, Higashimori T, Danton C, et al. (2005) Unraveling the Temporal Pattern of Diet-Induced Insulin Resistance in Individual Organs and Cardiac Dysfunction in C57BL/6 Mice. Diabetes 54: 3530-3540.

25. Thengchaisri N, Theerapun W, Kaewmokul S, Sastravaha A (2014) Abdominal obesity is associated with heart disease in dogs. BMC Veterinary Research 10: 131 .

26. Bodey AR, Michell AR (1996) Epidemiological study of blood Sressure in omestic dogs. Journal of Small Animal Practice 37: 116-125.
27. Gregory SP (1994) Developments in the understanding of the pathophysiology of urethral sphincter mechanism incompetence in the bitch. British Veterinary Journal 150: 135-150.

28. Sonnenschein EG, Glickman LT, Goldschmidt MH, McKee LJ (1991) Body conformation, diet, and risk of breast cancer in pet dogs: A casecontrol study. American Journal of Epidemiology 133: 694-703.

29. Lekcharoensuk C, Lulich JP, Osborne CA, Pusoonthornthum R, Allen TA, et al. (2000) Patient and environmental factors associated with calcium oxalate urolithiasis in dogs. Journal of the American Veterinary Medical Association 217: 515-519.

30. Leslee LS, Emily W, Hui S, Joan S, Eric V, et al. (2005) Weight loss: A novel and effective treatment for urinary incontinence. Journal of Urology 174: 190-195.

31. Heo K, Odle J, Han IK, Cho W, Seo S, et al. (2000) Dietary L-Carnitine Improves Nitrogen Utilization in Growing Pigs Fed Low Energy, FatContaining Diets. The Journal of Nutrition 130: 1809-1814.

32. Kennedy A, Martinez K, Schmidt S, Mandrup S, Point KL, et al. (2010) Antiobesity mechanisms of action of conjugated linoleic acid. The Journal of Nutritional Biochemistry 21: 171-179.

33. Titos E, Clària J (2013) Omega-3-derived mediators counteract obesityinduced adipose tissue inflammation. Prostaglandins \& Other Lipid Mediators 107: 77-84.

34. Kurzman ID, Panciera DL, Miller JB, MacEwen EG (1998) The effect of dehydroepiandrosterone combined with a low-fat diet in spontaneously obese dogs: A clinical trial. Obesity Research 6: 20-28.

35. Borne AT, Wolfsheimer KJ, Truett AA, Kiene J, Wojciechowski T, et al. (1996) Differential metabolic effects of energy restriction in dogs using diets varying in fat and fiber content. Obesity Research 4: 337-345.

36. van Dale D, Saris WH (1989) Repetitive weight loss and weight regain: Effects on weight reduction, resting metabolic rate, and lipolytic activity before and after exercise and/or diet treatment. The American Journal of Clinical Nutrition 49: 409-416.

37. Kushner RF, Blatner DJ, Jewell DE, Rudloff K (2006) The PPET Study: People and Pets Exercising Together. Obesity 14: 1762-1770.

38. Ramsey I, Holden SL (2009) Advances in the management of obesity in dogs. Veterinary Nursing Journal 24: 16-24. 


\section{II \\ нетан}

Advances In Industrial Biotechnology | ISSN: 2639-5665

Advances In Microbiology Research | ISSN: 2689-694X

Archives Of Surgery And Surgical Education | ISSN: 2689-3126

Archives Of Urology

Archives Of Zoological Studies | ISSN: 2640-7779

Current Trends Medical And Biological Engineering

International Journal Of Case Reports And Therapeutic Studies | ISSN: 2689-310X

Journal Of Addiction \& Addictive Disorders | ISSN: 2578-7276

Journal Of Agronomy \& Agricultural Science | ISSN: 2689-8292

Journal Of AIDS Clinical Research \& STDs | ISSN: 2572-7370

Journal Of Alcoholism Drug Abuse \& Substance Dependence | ISSN: 2572-9594

Journal Of Allergy Disorders \& Therapy | ISSN: 2470-749X

Journal Of Alternative Complementary \& Integrative Medicine | ISSN: 2470-7562

Journal Of Alzheimers \& Neurodegenerative Diseases | ISSN: 2572-9608

Journal Of Anesthesia \& Clinical Care | ISSN: 2378-8879

Journal Of Angiology \& Vascular Surgery | ISSN: 2572-7397

Journal Of Animal Research \& Veterinary Science | ISSN: 2639-3751

Journal Of Aquaculture \& Fisheries | ISSN: 2576-5523

Journal Of Atmospheric \& Earth Sciences | ISSN: 2689-8780

Journal Of Biotech Research \& Biochemistry

Journal Of Brain \& Neuroscience Research

Journal Of Cancer Biology \& Treatment | ISSN: 2470-7546

Journal Of Cardiology Study \& Research | ISSN: 2640-768X

Journal Of Cell Biology \& Cell Metabolism | ISSN: 2381-1943

Journal Of Clinical Dermatology \& Therapy | ISSN: 2378-8771

Journal Of Clinical Immunology \& Immunotherapy | ISSN: 2378-8844

Journal Of Clinical Studies \& Medical Case Reports | ISSN: 2378-8801

Journal Of Community Medicine \& Public Health Care | ISSN: 2381-1978

Journal Of Cytology \& Tissue Biology | ISSN: 2378-9107

Journal Of Dairy Research \& Technology | ISSN: 2688-9315

Journal Of Dentistry Oral Health \& Cosmesis | ISSN: 2473-6783

Journal Of Diabetes \& Metabolic Disorders | ISSN: 2381-201X

Journal Of Emergency Medicine Trauma \& Surgical Care | ISSN: 2378-8798

Journal Of Environmental Science Current Research | ISSN: 2643-5020

Journal Of Food Science \& Nutrition | ISSN: 2470-1076

Journal Of Forensic Legal \& Investigative Sciences | ISSN: 2473-733X

Journal Of Gastroenterology \& Hepatology Research | ISSN: 2574-2566
Journal Of Genetics \& Genomic Sciences | ISSN: 2574-2485

Journal Of Gerontology \& Geriatric Medicine | ISSN: 2381-8662

Journal Of Hematology Blood Transfusion \& Disorders | ISSN: 2572-2999

Journal Of Hospice \& Palliative Medical Care

Journal Of Human Endocrinology | ISSN: 2572-9640

Journal Of Infectious \& Non Infectious Diseases | ISSN: 2381-8654

Journal Of Internal Medicine \& Primary Healthcare | ISSN: 2574-2493

Journal Of Light \& Laser Current Trends

Journal Of Medicine Study \& Research | ISSN: 2639-5657

Journal Of Modern Chemical Sciences

Journal Of Nanotechnology Nanomedicine \& Nanobiotechnology | ISSN: 2381-2044

Journal Of Neonatology \& Clinical Pediatrics | ISSN: 2378-878X

Journal Of Nephrology \& Renal Therapy | ISSN: 2473-7313

Journal Of Non Invasive Vascular Investigation | ISSN: 2572-7400

Journal Of Nuclear Medicine Radiology \& Radiation Therapy | ISSN: 2572-7419

Journal Of Obesity \& Weight Loss | ISSN: 2473-7372

Journal Of Ophthalmology \& Clinical Research | ISSN: 2378-8887

Journal Of Orthopedic Research \& Physiotherapy | ISSN: 2381-2052

Journal Of Otolaryngology Head \& Neck Surgery | ISSN: 2573-010X

Journal Of Pathology Clinical \& Medical Research

Journal Of Pharmacology Pharmaceutics \& Pharmacovigilance | ISSN: 2639-5649

Journal Of Physical Medicine Rehabilitation \& Disabilities | ISSN: 2381-8670

Journal Of Plant Science Current Research | ISSN: 2639-3743

Journal Of Practical \& Professional Nursing | ISSN: 2639-5681

Journal Of Protein Research \& Bioinformatics

Journal Of Psychiatry Depression \& Anxiety | ISSN: 2573-0150

Journal Of Pulmonary Medicine \& Respiratory Research | ISSN: 2573-0177

Journal Of Reproductive Medicine Gynaecology \& Obstetrics | ISSN: 2574-2574

Journal Of Stem Cells Research Development \& Therapy | ISSN: 2381-2060

Journal Of Surgery Current Trends \& Innovations | ISSN: 2578-7284

Journal Of Toxicology Current Research | ISSN: 2639-3735

Journal Of Translational Science And Research

Journal Of Vaccines Research \& Vaccination | ISSN: 2573-0193

Journal Of Virology \& Antivirals

Sports Medicine And Injury Care Journal | ISSN: 2689-8829

Trends In Anatomy \& Physiology | ISSN: 2640-7752

Submit Your Manuscript: https://www.heraldopenaccess.us/submit-manuscript 